Prepared in cooperation with the Pennsylvania Department of Environmental Protection

\title{
Velocity, Water-Quality, and Bathymetric Surveys of the Grays Landing and Maxwell Navigation Pools, and Selected Tributaries to the Monongahela River, Pennsylvania, 2010-11
}

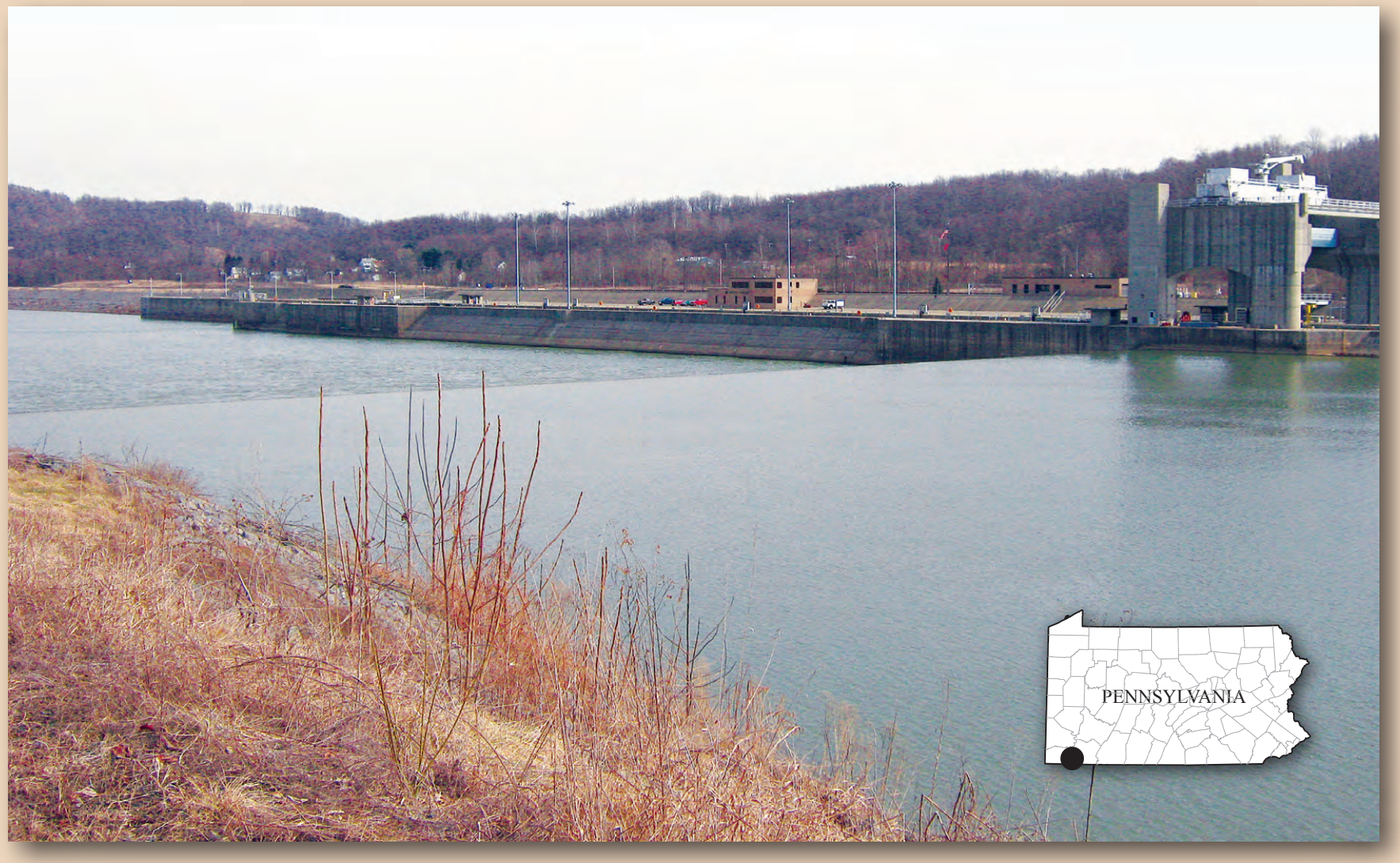

Data Series 784 
Cover. Grays Landing Lock and Dam on the Monongahela River, Grays Landing, Pennsylvania. Photograph by John W. Fulton, U.S. Geological Survey. 


\section{Velocity, Water-Quality, and Bathymetric Surveys of the Grays Landing and Maxwell Navigation Pools, and Selected Tributaries to the Monongahela River, Pennsylvania, 2010-11}

By Scott A. Hoffman, Mark A. Roland, Luther F. Schalk, and John W. Fulton

Prepared in cooperation with the

Pennsylvania Department of Environmental Protection

Data Series 784 


\title{
U.S. Department of the Interior SALLY JEWELL, Secretary
}

\section{U.S. Geological Survey Suzette M. Kimball, Acting Director}

\author{
U.S. Geological Survey, Reston, Virginia: 2013
}

For more information on the USGS - the Federal source for science about the Earth, its natural and living resources, natural hazards, and the environment, visit http://www.usgs.gov or call 1-888-ASK-USGS.

For an overview of USGS information products, including maps, imagery, and publications, visit http://www.usgs.gov/pubprod

To order this and other USGS information products, visit http://store.usgs.gov

Any use of trade, firm, or product names is for descriptive purposes only and does not imply endorsement by the U.S. Government.

Although this information product, for the most part, is in the public domain, it also may contain copyrighted materials as noted in the text. Permission to reproduce copyrighted items must be secured from the copyright owner.

Suggested citation:

Hoffman, S.A., Roland, M.R, Schalk, L.F., and Fulton, J.W., 2013, Velocity, water-quality, and bathymetric surveys of the Grays Landing and Maxwell Navigation Pools, and Selected Tributaries to the Monongahela River, Pennsylvania, 2010-11: U.S. Geological Survey Data Series 784, 12 p., http://pubs.usgs.gov/ds/784/. 


\section{Acknowledgments}

The authors thank the staff of the U.S. Army Corps of Engineers at Maxwell, Grays Landing, and Point Marion Locks and Dams for their help and cooperation on this project. Richard Spears of the Pennsylvania Department of Environmental Protection, Southwestern Regional Office, is thanked for field assistance with data collection. Brian Hattenbach, Abigail Crosby, Mike Langland, Jamie McCoy, Tom Noonan, Don Yezerski of the U.S. Geological Survey (USGS) and Dane Bralich, undergraduate engineering student at the Pennsylvania State University, are thanked for field assistance with data-collection activities. Thanks go to Linda Zarr (USGS) who compiled and processed the massive amount of field-collected data files and Tammy Zimmerman (USGS) for her extensive and thoughtful review of this report. Tom Ruby (USGS) and Mike Langland (USGS) are acknowledged and thanked for their thorough colleague reviews. 


\section{Contents}

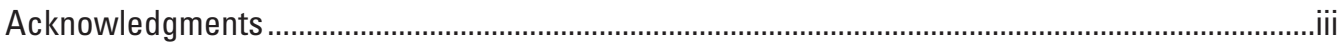

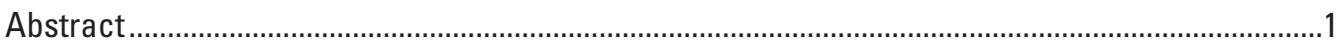

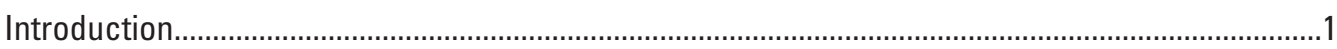

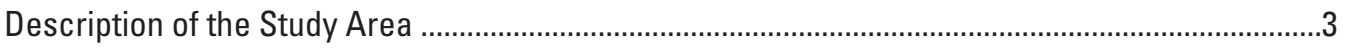

Methods of Investigation .........................................................................................................

Selection of Transects ......................................................................................................

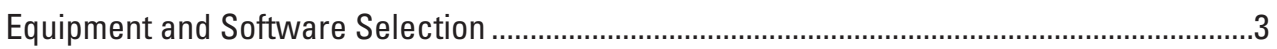

Velocity, Water-Quality, and Bathymetric Data Collection and Processing ..............................

Phase 1-Velocity and Water-Quality Data ..................................................................

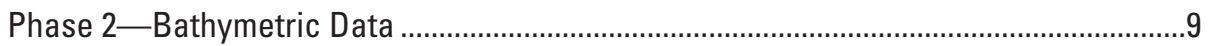

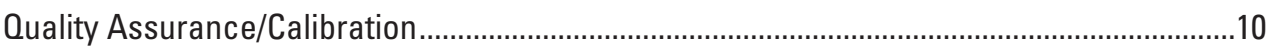

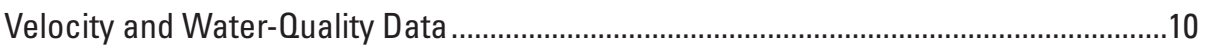

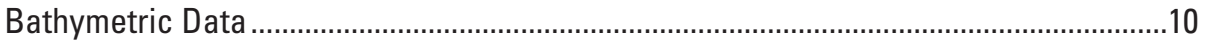

Summary

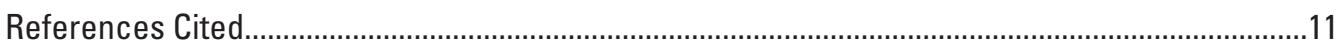

Appendix 1. Access database of water-quality and bathymetric data in the Gray's Landing and Maxwell navigation pools ............................................................................................12

\section{Figures}

1. Map showing Monongahela River and selected tributaries in Fayette, Greene, and Washington Counties, Pennsylvania

2. Map showing Grays Landing navigation pool in the Monongahela River, Pennsylvania.

3. Map showing Maxwell navigation pool in the Monongahela River, Pennsylvania...........5

4. Map showing transects where velocity, water-quality, and bathymetric data were collected in the Grays Landing navigation pool, Monongahela River,

Pennsylvania

5. Map showing transects where velocity, water-quality, and bathymetric data were collected in the Maxwell navigation pool, Monongahela River, Pennsylvania

6. Photograph of laser range finder and compass module operated from the GPS antenna...

7. Photograph of Kemmerer Sampler used to collect discrete surface-water samples at selected depths and locations. 


\section{Conversion Factors and Datums}

Inch/Pound to SI

\begin{tabular}{lcc}
\hline \multicolumn{1}{c}{ Multiply } & By & To obtain \\
\hline & Length & \\
\hline mile $(\mathrm{mi})$ & 1.609 & kilometer $(\mathrm{km})$ \\
\hline square $\mathrm{mile}\left(\mathrm{mi}^{2}\right)$ & Area & \\
\hline & 2.590 & square kilometer $\left(\mathrm{km}^{2}\right)$ \\
\hline cubic foot per second $\left(\mathrm{ft}^{3} / \mathrm{s}\right)$ & Flow rate & \\
\hline
\end{tabular}

Vertical coordinate information is referenced to the North American Vertical Datum of 1988 (NAVD 88).

Horizontal coordinate information is referenced to the North American Datum of 1983 (NAD 83).

Elevation, as used in this report, refers to distance above the vertical datum. 
(This page intentionally left blank.) 


\title{
Velocity, Water-Quality, and Bathymetric Surveys of the Grays Landing and Maxwell Navigation Pools, and selected tributaries to the Monongahela River, Pennsylvania, 2010-11
}

\author{
By Scott A. Hoffman, Mark A. Roland, Luther F. Schalk, and John W. Fulton
}

\begin{abstract}
The U.S. Geological Survey (USGS) conducted velocity, water-quality, and bathymetric surveys from spring 2010 to summer 2011 in the Grays Landing and Maxwell navigation pools of the Monongahela River, Pennsylvania, and selected tributaries in response to elevated levels of total dissolved solids (TDS) recorded in early September 2009. Velocity data were collected using an Acoustic Doppler Current Profiler. Water-quality surveys included the in-situ collection of specific-conductance, water-temperature, and turbidity data using a water-quality sonde. Additionally, discrete water samples were collected and analyzed for TDS, chloride, and sulfate. Bathymetric data were collected using an echo sounder, and the shoreline was delineated using a laser range finder and electronic compass. The data were geo-referenced using a differential global positioning system and navigational software. Horizontal $(\mathrm{x}, \mathrm{y})$ coordinates were referenced to the North American Datum of 1983. Depth (z) elevations were referenced to the North American Vertical Datum of 1988. The data are provided in electronic format (appendix 1) and may be downloaded and can be used in a geographic information system for cartographic display and data analysis.
\end{abstract}

\section{Introduction}

Elevated concentrations of total dissolved solids (TDS), ranging from 438 parts per million (ppm) to $908 \mathrm{ppm}$, were reported for water-quality monitoring stations near the mouth of the Monongahela River and upstream in the Monongahela River to the West Virginia border in early September 2009 (Reuters, 2009). In August 2010, the Pennsylvania Department of Environmental Protection issued a new drinking-water standard of $500 \mathrm{ppm}$ for TDS. (PACODE, 2010).

In response to the elevated TDS levels in the Monongahela River, the U.S. Geological Survey (USGS) and the Pennsylvania Department of Environmental Protection (PADEP) initiated a cooperative program to conduct hydrographic and water-quality surveys that included collection of velocity, water-quality, and bathymetric data in parts of the Monongahela River and selected tributaries (fig. 1). The objectives of the program were to (1) acquire accurate geo-referenced data and (2) provide data files for geo-referenced data. The term geo-referenced data refers to data with geographic information included, such as latitude and longitude. The data can be used in a geographic information system (GIS) for further analysis and display or as input to water-quality models used to assess the mixing-component potential in large rivers.

This report presents velocity, water-quality, and bathymetric data collected from spring 2010 to summer 2011 in the Grays Landing and Maxwell navigation pools in the Monongahela River and selected tributaries between the Point Marion Lock and Dam near Point Marion, Pennsylvania, and downstream to the Maxwell Lock and Dam near Fredericktown, Pa. Data were collected along pre-determined transects throughout the study area and at selected, discrete locations. Using a water-quality sonde, data were collected in-situ for specific conductance, turbidity, and water temperature along river transects during periods of high and low flows. Water samples collected at discrete locations were analyzed for sulfate, chloride, and TDS. The report also summarizes the methods and equipment used to collect and process the data. Specific hourly conditions and characteristics for water temperature, air temperature, and changing stages can be examined by accessing the database (appendix 1). The data are provided in electronic format and may be downloaded for further study or may be incorporated into various GIS and other digital mapping applications. 


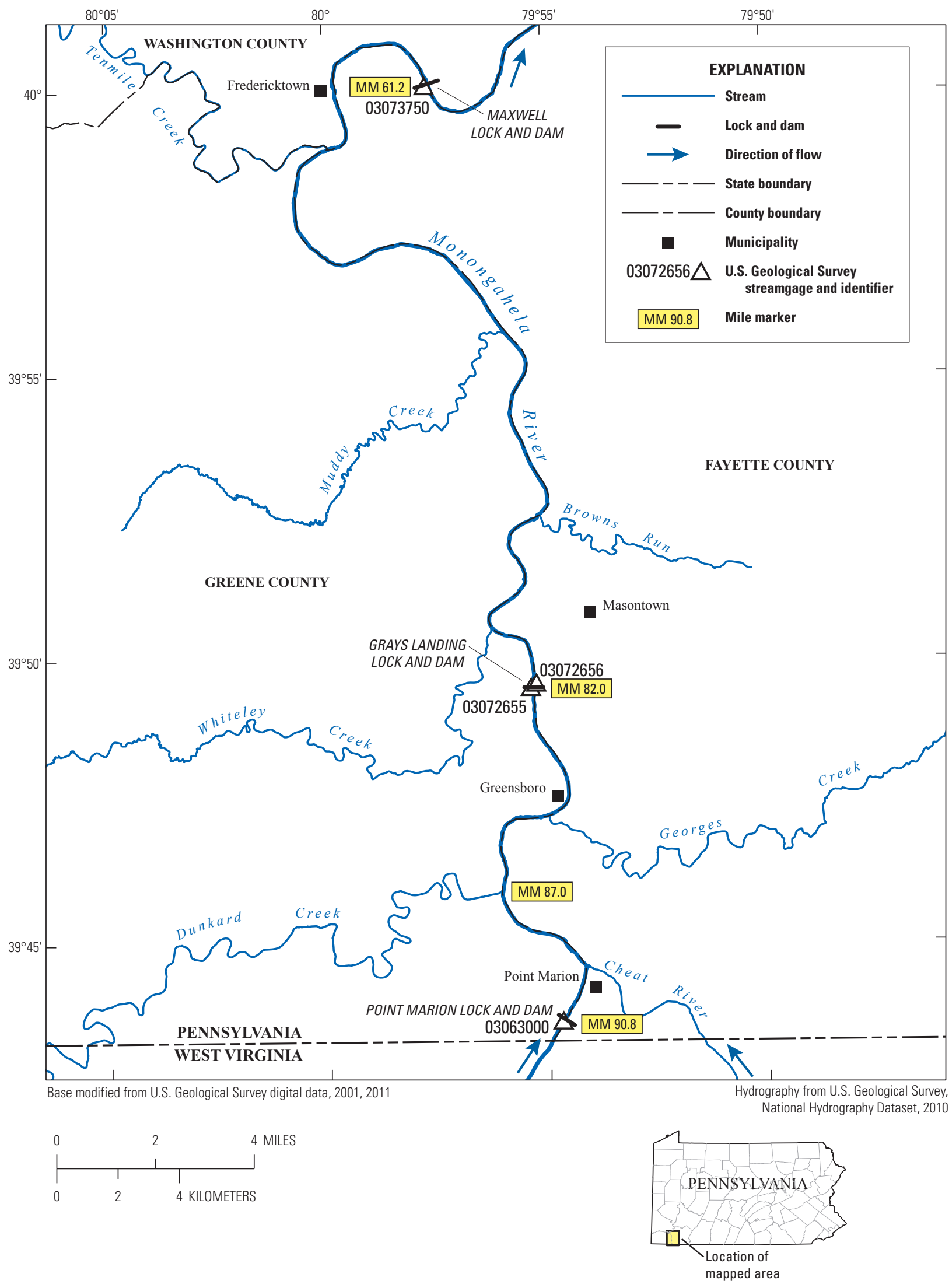

Figure 1. Monongahela River and selected tributaries in Fayette, Greene, and Washington Counties, Pennsylvania. 


\section{Description of the Study Area}

The study area includes parts of the Monongahela River and selected tributaries downstream from the Point Marion Lock and Dam (mile marker MM 90.8) to the Maxwell Lock and Dam (MM 61.2) (fig. 1). The Grays Landing and Maxwell navigation pools are two of nine navigational structures operated by the U.S. Army Corps of Engineers (USACE) on the Monongahela River that provide for year-long navigation between Pittsburgh, Pa., and Fairmont, West Virginia. The Grays Landing navigation pool (fig. 2) is maintained as part of the Grays Landing Lock and Dam (MM 82.0) and extends approximately 8.8 miles upstream to the Point Marion Lock and Dam (MM 90.8). Grays Landing navigation pool is the receiving water for three major tributaries; parts of two of the tributaries - Cheat River and Dunkard Creek - were included in the hydrographic and water-quality surveys. The Maxwell navigation pool (fig. 3) is maintained as part of the Maxwell Lock and Dam (MM 61.2) and extends approximately 20.8 miles upstream to the Grays Landing Lock and Dam. The Maxwell navigation pool receives water from Browns Run, Muddy Creek, Tenmile Creek, and Whiteley Creek (fig. 1). Because of depth limitations, only part of Tenmile Creek was included in the hydrographic and water-quality surveys.

\section{Methods of Investigation}

The primary tasks needed to complete the project included project preparation, data collection and processing, and quality assurance. The following sections describe the general methods, as well as the customized methods, used for this specific study.

\section{Selection of Transects}

Aerial photographs of the Grays Landing and Maxwell navigational pools and surrounding areas were acquired, geo-referenced, and used to establish locations of transects (cross-sections) within the study area to assist in navigating the boat during the hydrographic surveys. The transects were generated within a hydrographic software program called HYPACK ${ }^{\circledR}$, which is capable of time stamping and assimilating various data streams as a function of geographic position. The transects were spaced approximately 800 feet apart within the Grays Landing and Maxwell navigation pools (fig. 4 and fig. 5) and assigned a unique identifier for data-management purposes.

The transects were spaced at approximately equal increments throughout the study area; however, velocity, water-quality, and bathymetric data were not collected at all transects. Transects selected for data acquisition were determined by channel characteristics such as length, width, and meander and features such as bridges and confluence points of tributaries. In general, increasingly complex portions of channels or proximity to structures required additional transects to better define the stream with a representative data set.

\section{Equipment and Software Selection}

Collecting accurate, geo-referenced data was accomplished using a variety of field instruments. Equipment used in the hydrographic and water-quality surveys was assembled and tested before being deployed in the field to verify proper operation. The primary equipment employed for the project is summarized below.

- Boat to accommodate a crew of three or four people with an enclosed work area to protect the equipment from the elements.

- Hemisphere(C) Differential Global Positioning System (DGPS) to assist with navigation.

- YSIC 600 Optical Monitoring System (OMS) multiparameter water-quality sonde equipped to measure specific conductance, water temperature, and turbidity as functions of depth (YSI, 2008).

- Kemmerer water sampler to collect water samples at specified depths.

- Teledyne RDIC 1200 kilohertz (kHz) Acoustic Doppler Current Profiler (ADCP) mounted to the side of the boat to measure channel discharge, velocities, and depths at each transect.

- RESONC NaviSound $210 \mathrm{kHz}$ echo sounder and $200 \mathrm{kHz}$ ODOMC transducer (3-degree beam angle) to map the channel bottom below the water surface. The Navisound ${ }^{\circledR} 210$ Reson echo sounder has a depth range from 0.6 to 600 meters (m) (Reson, Inc., 2005).

- Laptop computer to run HYPACK ${ }^{\circledR}$ and WinRiver II software. HYPACK ${ }^{\circledR}$ is navigational software capable of time stamping and assimilating various data streams as a function of geographic position. WinRiver II is a software application used to collect and process ADCP data to compute streamflow.

- Helm monitor to view the HYPACK ${ }^{\circledR}$ display and facilitate navigation by allowing the boat operator to maintain a proper heading relative to a transect.

- Impulse 200 (Laser Technology, Inc.) laser range finder and electronic compass module (fig. 6) to measure the distance and azimuth from the boat to the river bank.

The DGPS, ADCP, and NaviSound provide data streams that are time-stamped and assimilated in HYPACK ${ }^{\circledR}$. Horizontal and depth data (x, y, z coordinates) collected using detailed, spatially accurate techniques can supply modeling software with specific data points for analysis. 


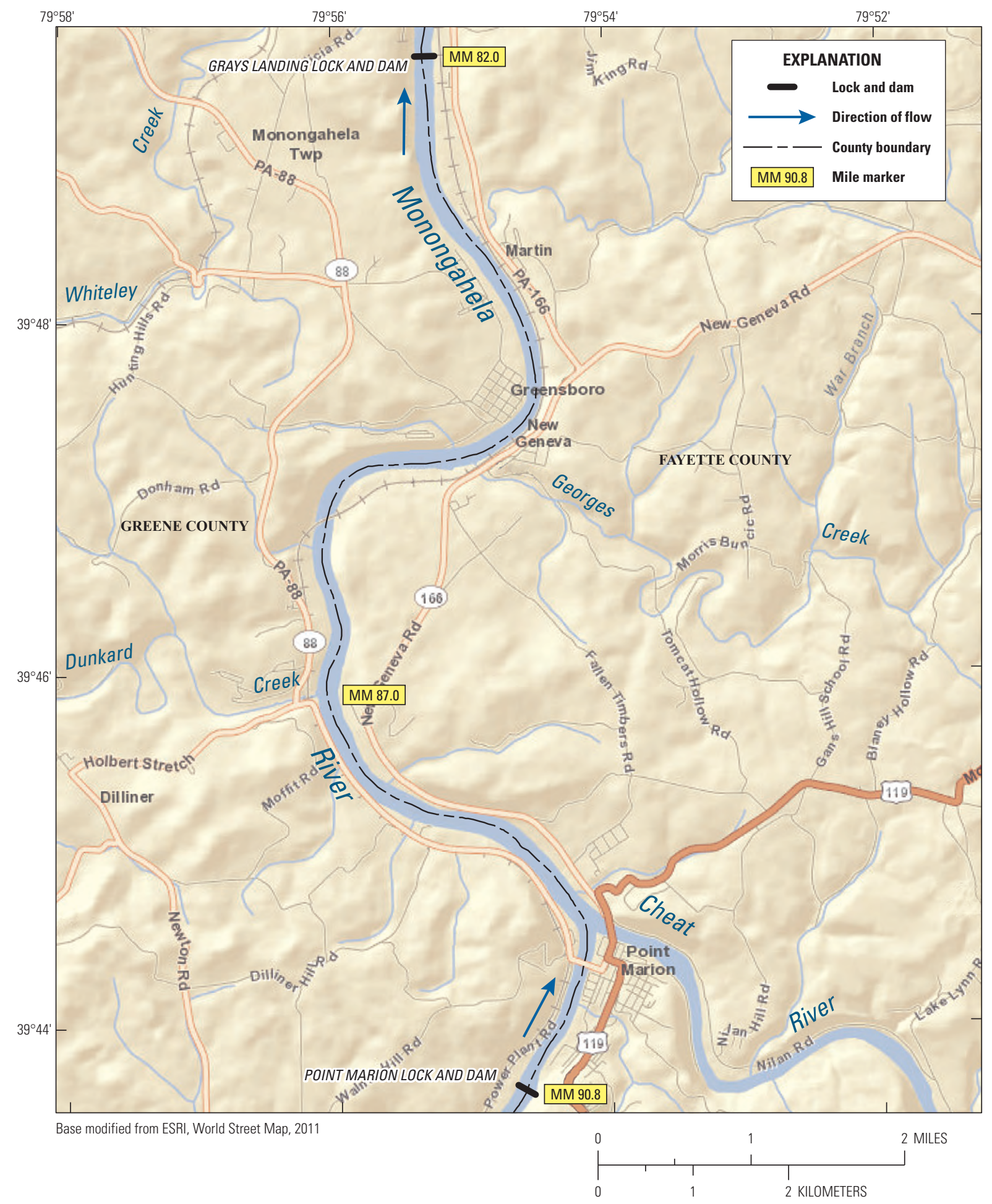

Figure 2. Grays Landing navigation pool in the Monongahela River, Pennsylvania. 


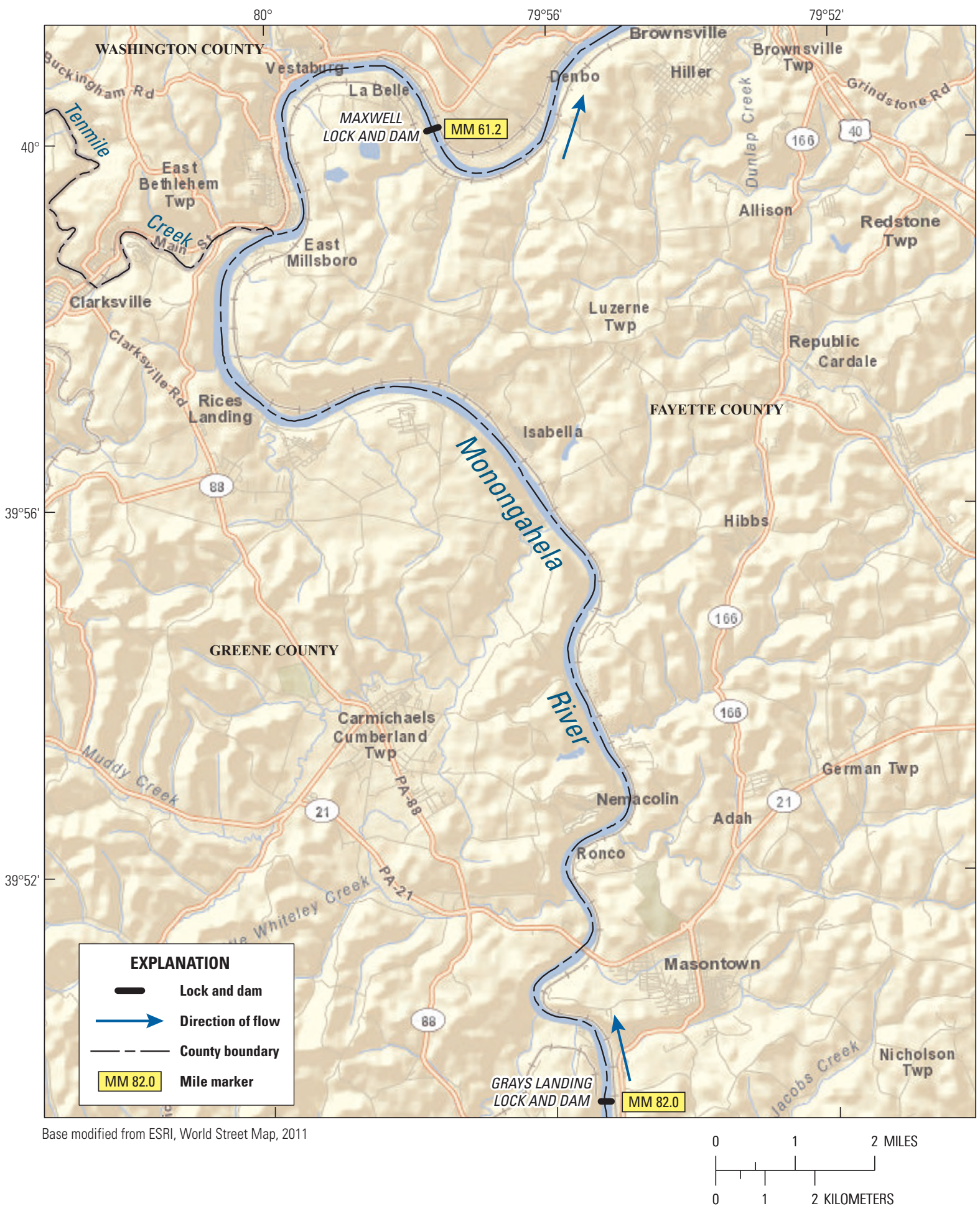

Figure 3. Maxwell navigation pool in the Monongahela River, Pennsylvania. 


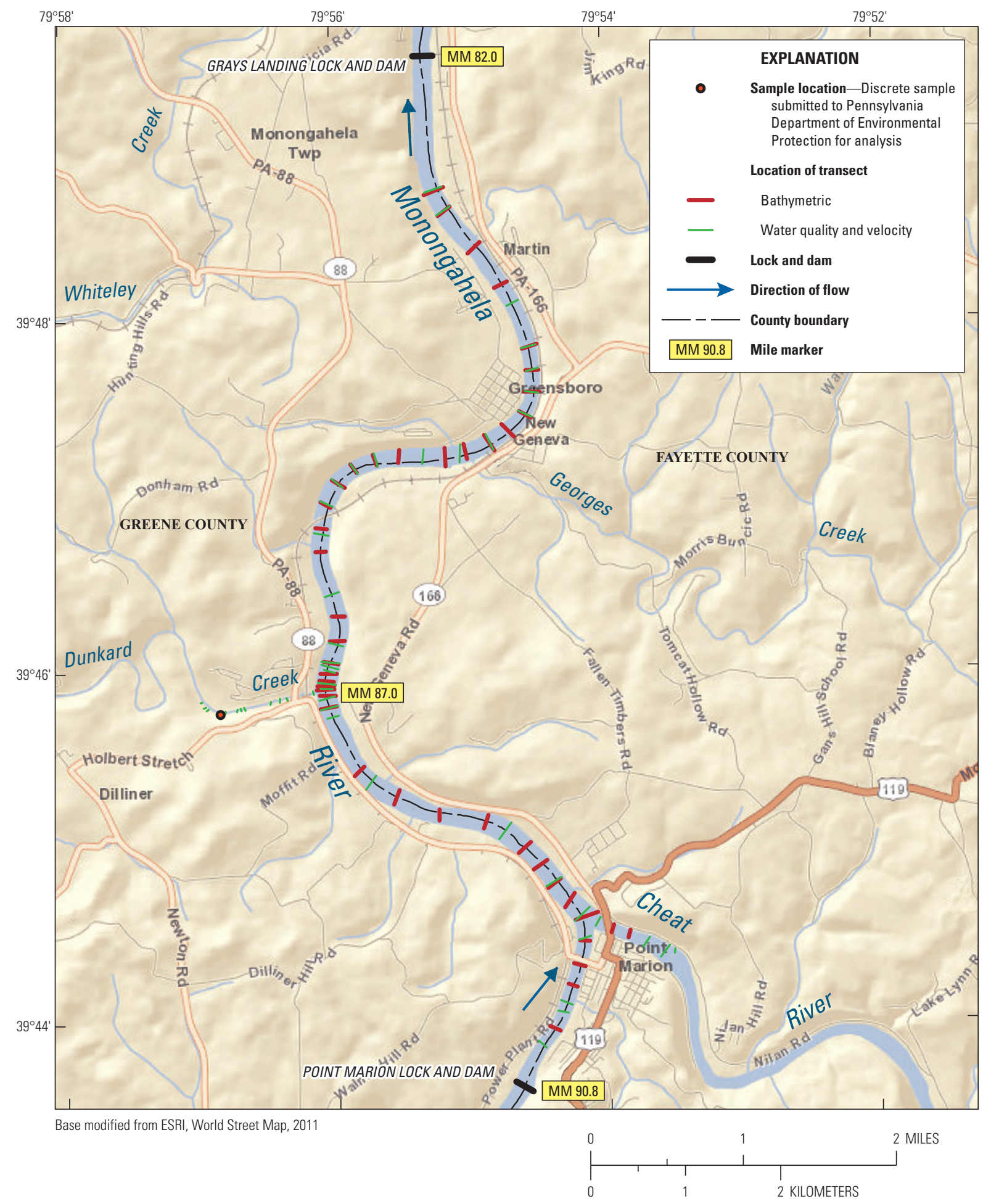

Figure 4. Transects where velocity, water-quality, and bathymetric data were collected in the Grays Landing navigation pool, Monongahela River, Pennsylvania. 


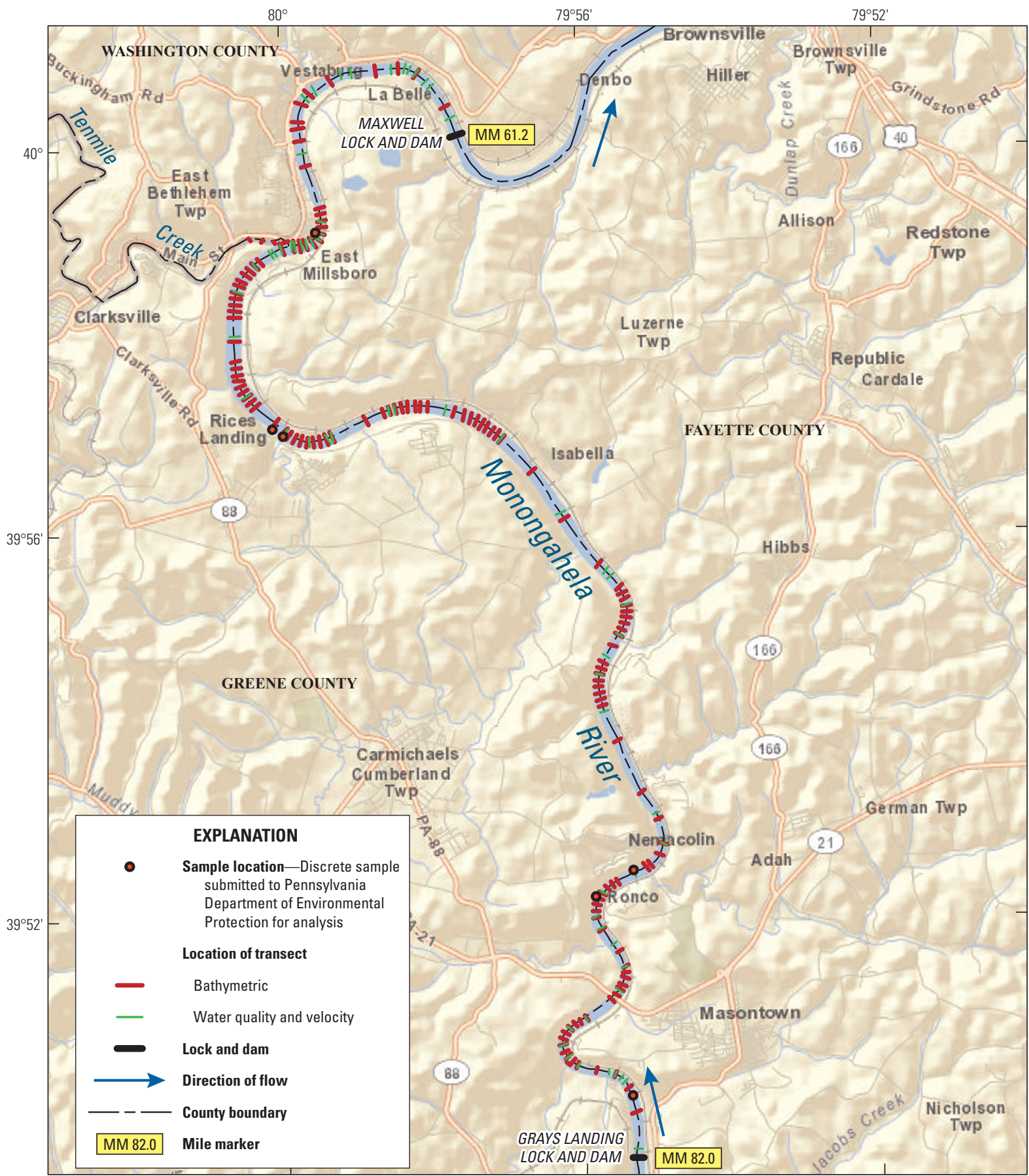

Base modified from ESRI, World Street Map, 2011

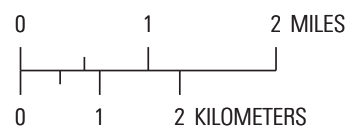

Figure 5. Transects where velocity, water-quality, and bathymetric data were collected in the Maxwell navigation pool, Monongahela River, Pennsylvania. 


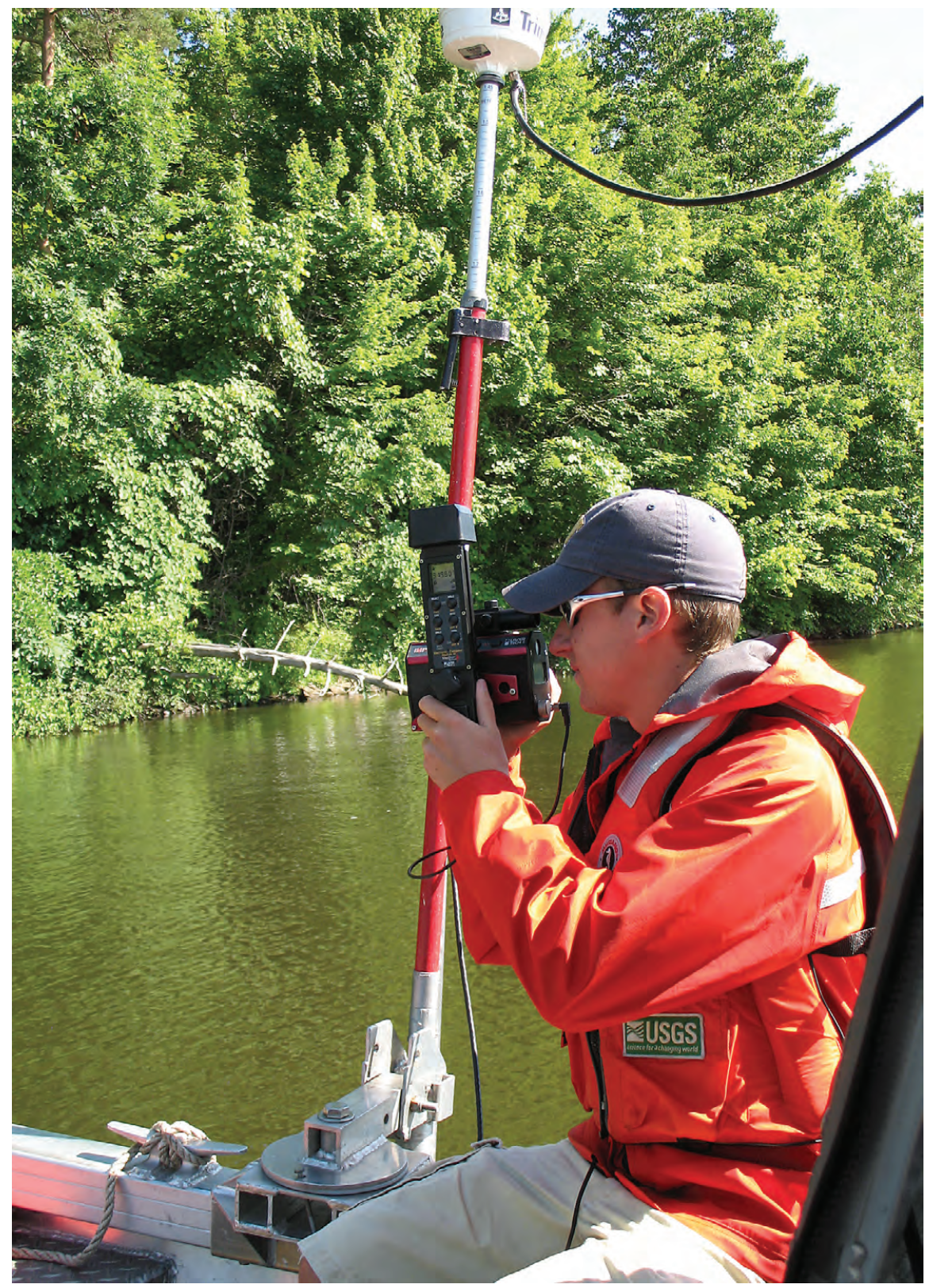

Figure 6. Laser range finder and compass module operated from the GPS antenna. (Photo from Hittle and Ruby, 2008)

\section{Velocity, Water-Quality, and Bathymetric Data Collection and Processing}

Velocity, water-quality, and bathymetric data were collected during Phase 1 and Phase 2 field efforts. Phase 1 focused on velocity and water-quality data, whereas Phase 2 focused on bathymetric data. Data collection was based on predetermined transect lines created in HYPACK ${ }^{\circledR}$. During Phase 1, the transect density (figs. 4 and 5) was selected to enable sufficient definition in areas where the velocity distribution was expected to vary (in the vicinity of meanders and structures). During Phase 2, transect selection to obtain bathymetric data (figs. 4 and 5) was based on channel width and meander. Water-surface elevations recorded at USGS streamgages on the Monongahela River (fig. 1) were used in conjunction with tape-down measurements at various locations to correlate channel bathymetry with the water surface during data collection. The streamgages used were the

- Monongahela River at Lock and Dam 8 at Point Marion (03063000),

- Monongahela River near Masontown (03072655),

- Monongahela River (Lower Pool) near Masontown (03072656), and

- Monongahela River at Maxwell Lock and Dam Upper Pool at Maxwell (03073750). 


\section{Phase 1-Velocity and Water-Quality Data}

During Phase 1, velocity, depth, and position were simultaneously recorded in WinRiver II and HYPACK ${ }^{\circledR}$. This information enabled the computation of discharge along transects within the study area. ADCP equipment was mounted on the starboard side of the boat, and a DGPS was mounted directly above the transducer. The depth of the transducer in the water was measured and entered as an offset into WinRiver II. Velocities were measured using the ADCP as a function of location (latitude and longitude). Typically, the ADCP unit operates at velocities up to \pm 5 meters per second $(\mathrm{m} / \mathrm{s})$ with a standard deviation of $0.4-14$ centimeters per second $(\mathrm{cm} / \mathrm{s})$ and depths ranging from 4 to 20 meters (m). Velocities were measured from approximately $0.3 \mathrm{~m}$ beneath the water surface to within 6 percent of the depth to the bottom. A laser range finder was used to measure the lateral distance from the DGPS unit to the water's edge in areas of the channel that could not be accessed by boat.

Field operations consisted of positioning the boat at a transect near the left or right bank, and a laser range finder was used to obtain the distance to edge of water. This information was entered into WinRiver II so an initial discharge measurement could be initiated. The boat operator then proceeded across the channel to the opposite end of the transect following the plan line on the computer monitor. As the boat approached the shoreline, the boat was stopped, held in position, and steadied to allow the operator of the laser range finder and equipment operator to mark the opposite end of the transect to enable computation of the discharge measurement.

The initial discharge measurement was divided into four equal sub-areas of discharge, each representing 25 percent of the initially measured streamflow, with the centroid of each sub-area at the locations 12.5 percent, 37.5 percent, 62.5 percent, and 87.5 percent of streamflow. These data were used to help determine locations along a transect where vertical profiles of specific conductance, water temperature, and turbidity were obtained with the water-quality sonde.

Once the discharges were determined for the sub-areas, a second discharge measurement was initiated along the same transect. The boat was navigated until a point was reached when 12.5 percent of the streamflow was computed by WinRiver II, indicating the centroid location of the first sub-area. The boat was stopped at this approximate location, and a vertical profile of water-quality data was obtained from the water surface to the channel bottom. The water-quality sonde used for collection of in-situ water-quality data was secured to a cable equipped with a 25 -pound sounding weight that could be raised or lowered vertically by means of a USGS bridge reel. The reel and cable were mounted on the port side of the boat. The sonde was connected to a laptop where it communicated with the HYPACK ${ }^{\circledR}$, which logged specific conductance, water temperature, and turbidity as a function of depth. This process was repeated along the transect for the remaining centroid locations $(37.5,62.5$, and 87.5 percent). Where possible, data also were collected along the left and right banks of a transect.

Water-quality data were collected at transects in the Grays Landing and Maxwell navigation pools at streamflows ranging from 200 to 41,300 cubic feet per second. The completed transects collected during the Grays Landing and Maxwell Pool surveys are shown on figures 4 and 5. During the survey, detailed notes were taken by the equipment operator to assist in processing the data. Each transect was processed with WinRiver II ${ }^{\circledR}$ software, in accordance with established USGS techniques (Mueller and Wagner, 2006).

Discrete water samples were collected at selected transect locations at various depths in Dunkard Creek (figs. 4 and 5) and the Grays Landing and Maxwell navigation pools using a Kemmerer sampler (fig. 7). The sampler was lowered on a graduated rope to a desired depth, which assured complete flushing of the bottle as it was lowered. Once the sampler reached the desired depth, both ends of the bottle were closed by means of a messenger weight, and the undisturbed sample was brought to the surface. The sample was then transferred to a smaller bottle by means of a drain in the lower end of the sampler. Sample bottles were submitted to Pennsylvania Department of Environmental Protection, Bureau of Laboratories, for TDS, sulfate, and chloride analyses. Samples were collected in accordance with Chapter A4 of the U.S. Geological Survey national field manual (U.S. Geological Survey, 2006).

\section{Phase 2-Bathymetric Data}

Phase 2 field work consisted of collecting bathymetric data at selected transects throughout the Grays Landing (fig. 4) and Maxwell (fig. 5) navigation pools. The number and selection of transects surveyed were based on river characteristics, and transects were spaced at intervals necessary to collect a representative data set. Personnel needed to carry out the

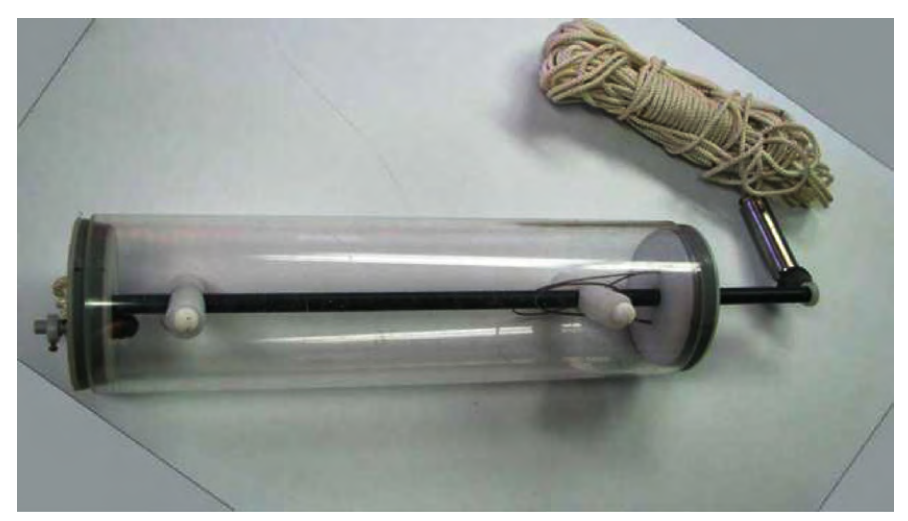

Figure 7. Kemmerer Sampler used to collect discrete surfacewater samples at selected depths and locations. 
field operation consisted of a boat crew of three persons: boat operator, laptop equipment operator, and operator of the laser range finder.

Similar to Phase 1, navigation within each pool was enhanced by means of the pre-established transect lines created in $\mathrm{HYPACK}{ }^{\circledR}$, which were viewed on-board during data collection. Using methods described by Hittle and Ruby (2008), at the start of the bathymetric survey the boat operator held the boat stationary on one side of the transect near the shore. The echo sounder and DGPS instrumentation were started, and depths and position data were simultaneously recorded within HYPACK ${ }^{\circledR}$. The operator of the laser range finder measured and recorded the distance and azimuth reading to the edge of water. Subsequently, a distance and bearing were entered to define a shoreline point relative to the position of the boat. The boat operator then navigated across the channel to the opposite end of the transect. As the boat approached the shoreline, the boat was stopped, held in position, and steadied to allow the operator of the laser range finder and laptop equipment operator to mark the ending shoreline location. The recording was stopped, and the crew proceeded to the next transect to repeat the process. Additionally, individual edge-of-water or target locations were surveyed at bridge piers and at the mouths of major tributaries to assist in the delineation of the channel geometry. During the survey, detailed notes were taken by the equipment operator to assist with data processing.

Data were processed, reviewed, and edited as necessary in the office. Raw bathymetric data were processed in HYPACK ${ }^{\circledR}$ to filter (1) multiple-return acoustic signals in shallow water, (2) corrupt DGPS signals, (3) redundant depths recorded near the banks caused by navigation limitations, and (4) erroneous spikes. The raw data were reviewed and edited using field notes and supporting data-collection documentation. After review and edit, the raw data were saved as edited data. The elevation of the channel bottom was determined by subtracting the edited water depth from the pool stage, which was referenced to NAVD88, reported from the lower and upper pool streamgages in the Grays Landing and Maxwell locks and dams. The edited data were exported digitally as horizontal $(\mathrm{x}, \mathrm{y})$ coordinates and depth $(\mathrm{z})$. These data can be used to produce cartographic products. Data files containing the edited data are available in appendix 1.

\section{Quality Assurance/Calibration}

Quality-assurance methods used to ensure data integrity included ADCP moving bed (loop) tests, ADCP compass calibrations, water-quality probe calibrations, a bar check for the echo sounder calibration, and periodic depth checks. The quality assurance associated with the field program is discussed in the following sections. A complete analysis of the accuracy of the horizontal (x, y) and depth (z) data was beyond the scope of this study.

\section{Velocity and Water-Quality Data}

A systematic bias in discharge measurements made with an ADCP is attributed to the movement of sediment near the streambed. This bias leads to an underestimation of measured velocity and discharge (Mueller and Wagner, 2006). To correct for this potential bias, multiple loop tests were performed in the Grays Landing and Maxwell navigation pools. A properly calibrated compass is critical to application of the loop method; therefore, compass calibrations were performed in accordance with the Teledyne RDIC $1200 \mathrm{kHz}$ Rio Grande ADCP Method 3. Simply put, Method 3 is a process for calibrating the ADCP compass that is based on local environmental conditions (Teledyne RD Instruments, 2007) and is documented routinely during data collection.

Protocols and quality-assurance measures previously established by the USGS for ADCP use were adopted to estimate the discharge in the unmeasured top and bottom portions of the profile (Simpson and Oltmann, 1991). Variations in streamflow from reservoir releases and hydropower operations resulted in oscillations in the streamflow hydrograph, particularly during low flows.

The horizontal position of the boat was measured using a DGPS receiver that acquired differential corrections from a local U.S. Coast Guard beacon. The receiver module is designed to work with software called Extended Differential (e-Dif). The software allows differential accuracy without using a differential service. In general, e-Dif provides submeter differential corrections for position; however, it is done internally in the unit using its own pseudo corrections (Hemisphere GPS, 2012). The DGPS unit is specified by the manufacturer to be accurate to $1 \mathrm{~m}$ at two standard deviations; tests and prior use of this unit indicate that typically about 80 percent of the data are within one meter of the true location (Hittle and Ruby, 2008).

The specific conductance and turbidity probes were calibrated prior to mobilizing and after returning from the field. The YSI user's manual (YSI Incorporated, 2008) provides information regarding communication and power options, sensor principles of operation, maintenance, and calibration.

\section{Bathymetric Data}

Various techniques were used to calibrate and verify the accuracy of the echo sounder. Prior to mobilization, the echo sounder was placed in a water-tank to measure the depth to the bottom of the tank and verify the speed of sound on the basis of the salinity and temperature of the water. Additionally, the USACE suggests performing the bar-check procedure to adequately calibrate a fathometer (U.S. Army Corps of Engineers, 2002). A built-in bar-check utility permitted depth verification using a speed of sound correction. The bar-check procedure was conducted in the field prior to the collection of depth data. The boat was held in position, and a 2 -ft by 4 -ft plate 
was lowered to a depth of $6 \mathrm{ft}$ below the transducer. The echo sounder displayed the depth, and, when stable, the unit was calibrated to establish the correct speed of sound setting used to compute depth. The accuracy of the bar check was verified daily during each field trip using a steel tape incremented to hundredths of feet. Wave action affected the precision of the measurement; consequently, a conservative estimate for the vertical accuracy of the echo sounder is \pm 0.5 feet. The water depths also were periodically checked for accuracy when water-quality data were being collected.

To assist in the documentation of changes in river stage during the surveys, a steel tape was used to periodically measure the vertical distance from a reference point to the water surface at prescribed tape-down locations. Typically, this was done along a river wall near a permanent structure such as a lock wall or mooring monument. These data could then be compared to continuous-stage readings at USGS streamgages.

\section{Summary}

In early September 2009, concentrations of total dissolved solids (TDS), ranging from 438 parts per million (ppm) to $908 \mathrm{ppm}$, were reported for water-quality monitoring stations located near the mouth of the Monongahela River and extending upstream in the Monongahela River to the West Virginia border. During 2010-11, the U.S. Geological Survey, in cooperation with the Pennsylvania Department of Environmental Protection, performed velocity, water-quality, and bathymetric surveys in the Grays Landing and Maxwell navigation pools of the Monongahela River, as well as the lower reaches of Dunkard Creek, Tenmile Creek, and the Cheat River. The objectives of these surveys were to collect geo-referenced velocity, water-quality, and bathymetric data and to assure the quality of the data collected. These data can be used in a geographic information system for cartographic display and data analysis.

To facilitate data collection and aid in boat navigation, transects were established at pre-determined intervals throughout the study area and displayed on a geo-referenced aerial photograph within HYPACK. The number and selection of transects surveyed were based on river characteristics, and transects were spaced at intervals necessary to collect a representative data set. Channel velocities and streamflow were measured using Acoustic Doppler Current Profiler equipment and WinRiver II software. Water-quality surveys included the in-situ collection of specific-conductance, water temperature, and turbidity data using a depth-integrated method and a water-quality sonde. Additionally, discrete water samples were collected and analyzed for TDS, chloride, and sulfate. Bathymetric data were collected using an echo sounder.

Data were managed and assembled using HYPACK ${ }^{\circledR}$ and post processing of the raw bathymetric data sets eliminated erroneous spikes. Channel-bed data are presented in coordinate $(\mathrm{x}, \mathrm{y}, \mathrm{z})$ format. Horizontal $(\mathrm{x}, \mathrm{y})$ coordinates are referenced to the North American Datum of 1983. Channelbottom elevations $(\mathrm{z})$ are referenced to the North American Vertical Datum of 1988.

\section{References Cited}

Hemisphere GPS, 2012,e-Dif - Extended differential option for the crescent receiver, accessed September 25, 2012, at http://www.hemispheregps.com/gpstechinfo/e-Dif_Overview. htm.

Hittle, C.D., and Ruby, A.T., III, 2008, Bathymetric surveys of Lake Arthur and Raccoon Lake, Pennsylvania, June 2007: U.S. Geological Survey Data Series 357, 10 p.

Mueller, D.S., and Wagner, C.R., 2006. Application of the loop method for correcting Acoustic Doppler Current Profiler discharge measurements biased by sediment transport: U.S. Geological Survey Scientific Investigations Report 20065079, $18 \mathrm{p}$.

PACODE, 2010, Chapter 95 - Wastewater treatment requirements, accessed September 25, 2012, at http://www.pacode. com/secure/data/025/chapter95/chap95toc.html.

Reson, Inc., 2005, NaviSound 200/400 users guide: Navisound $^{\mathrm{TM}} 100,200 \& 400$ Series Operator's Manual, version $4.01,177 \mathrm{p}$.

Reuters, 2009, Total dissolved solids in Monongahela River drop significantly below state, Federal limits, accessed September 25, 2012, at $h t t p: / / w w w . r e u t e r s . c o m / a r t i c l e /$ pressRelease/idUS234872+21-Jan-2009+PRN20090121.

Simpson, M.R., and Oltmann, R.N., 1991. Discharge-measurement system using an Acoustic Doppler Current Profiler with applications to large rivers and estuaries: U.S. Geological Survey Water-Resources Investigations Report 91-487, $49 \mathrm{p}$.

Teledyne RD Instruments, 2007, WinRiver II user's guide: San Diego, Teledyne RD Instruments, CA, P/N 957-6231-00, $166 \mathrm{p}$.

U.S. Army Corps of Engineers, 2002, Engineering and design - hydrographic surveying manual no. 1110-2-1003: Washington, D.C., $510 \mathrm{p}$.

U.S. Geological Survey, 2006, Collection of water samples (ver. 2.0): U.S. Geological Survey Techniques of WaterResources Investigations, book 9, chap. A4, September 2006, accessed September 6, 2011, at http://pubs.water. usgs.gov/twri9A4/.

YSI, Incorporated, 2008, 6-Series multiparameter water quality sondes user's manual, accessed July 2011 at $h t t p: / / w w w$. ysi.com/media/pdfs/069300-YSI-6-Series-Manual-RevF.pdf. 
12 Surveys of the Grays Landing and Maxwell Navigation Pools, and Tributaries to the Monongahela River, Pa., 2010-11

\section{Appendix 1. Access database of water-quality and bathymetric data in the Gray's Landing and Maxwell navigation pools}

(Available online at: http://pubs.usgs.gov/ds/784/) 
For additional information:

Director

U.S. Geological Survey

Pennsylvania Water Science Center

215 Limekiln Road

New Cumberland, PA 17070

http://pa.water.usgs.gov/ 


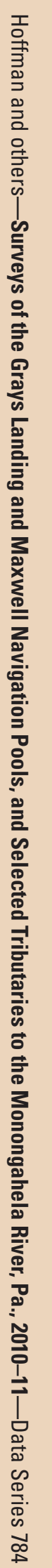

